Yochanan Altman, Roman Batko, Mark Davies, and Katarzyna Baliga-Nicholson

\title{
The Online Trade and Consumption of Jewish Figurines and Pictures of Jewish Figures in Contemporary Poland: An Antisemitic Discourse?
}

The selling and buying of Jewish male figurines featured in traditional Orthodox clothes, made mostly of wood but also of metal, ceramics, and plastic, as talisman or souvenir, are widespread in contemporary Poland. Of interest is the way these figurines are depicted: presented with a coin or moneybag, which is supposed to usher in good luck and wealth to its owner. In this paper we investigate the trade of figurines and pictures of Jews on the internet, whereby producers are provided with a platform of direct communication with buyers. We pay particular attention to the tone and contents of the statements. We also examine relevant discussion forums and analyze the discourse presented.

Our findings show that the online communication evolves around comments, testimonials, and related data, mostly describing the potency of these artefacts and the treatment they require in order to deliver prosperity. The discourse surrounding this phenomena can and should be read in relation to the broader historical and contemporary socio-political context, which grounds its understanding and helps to uncover the undertow of what seems at first glance to be neutral or even positive disposition but altogether continues and enshrines the well trodden path of anti-Jewish sentiment.

\section{Introduction}

The online trade company Jubileo.pl offers a description of the figurine as follows:

Presenting a Jew with a pouch or money as an amulet for financial success has become popular at the beginning of the twenty-first century. Image of the Jew is stereotyped-it's an older man, bearded, with side curls and a yarmulke, gabardine or pelisse, well groomed. The proverb "Jew in the hallway, money in the pocket" provides advice where the picture

Note: This research was supported by a Small Research Grant of the British Academy.

Ә OpenAccess. ( 2021 Armin Lange, Kerstin Mayerhofer, Dina Porat, Lawrence H. Schiffmann, published by De Gruyter. (cc)BY-NC-ND This work is licensed under the Creative Commons Attribution-NonCommercialNoDerivatives 4.0 International License. https://doi.org/10.1515/9783110671964-013 
(or figurine) should be hanged, and there are numerous instructions for placing the image of a Jew at home. First of all, a Jew should be taken from someone, it is not good enough to buy a figurine. The second rule is hanging or putting it upside down once in a while, so that the money collected by the Jew pours out of his pouch and stays at home. Third, it is advantageous to have the Jew holding real money, in the frame (of the picture) or in the (figure's) hand. Adhering to these principles will bring financial wealth with the Jew. ${ }^{1}$

Jews in today's Poland comprise but a minuscule share of the population-less than $0.01 \% .^{2}$ Hence the great majority of Poles have never met a Jew in their life. Jews, however, occupy a significant space in the Polish institutional, cultural, as well as popular psyche, validating Diana Pinto's observation that "the larger

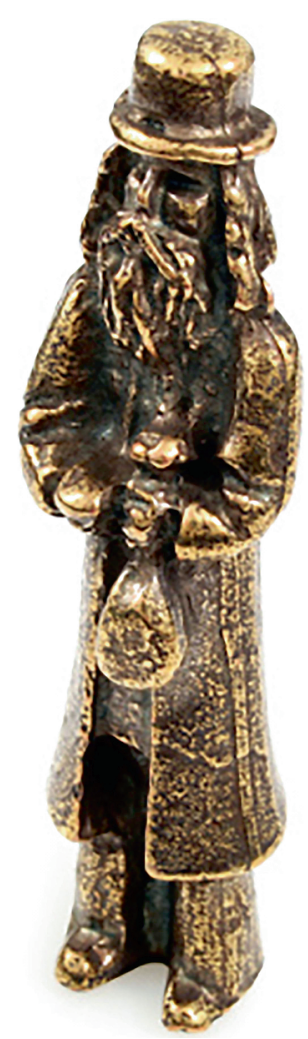

Fig. 1: Figurine of Jew with a Pouch, Symbol of Fortune [Jubileo.pl, Figurka Żyd z skaiewką. Symbol fortuny.] Source: https://www.jubi leo.pl/figurka-zyd-z-sakiewka-942.html. Accessed May 26, 2020.

1 https://www.jubileo.pl/figurka-zyd-z-sakiewka-942.html, accessed April 18, 2019. Translation by the authors of this article.

2 Cf. A. Sułek, "Ordinary Poles Look at the Jews," East European Politics and Societies and Cultures 26, no. 2 (2012): 425-44. 
the 'Jewish space,' the smaller the number of actual Jews."' Against a backdrop of rapid and genuine growth of interest in Jewish matters over the past thirty years, ${ }^{4}$ as well as a gradual rise in neutral and positive sentiments toward Jews, ${ }^{5}$ opposite developments stand out. For example, the 2018 controversial "memory law" radically restricting freedom of speech about Polish complicity in the Holocaust; ${ }^{6}$ the recent avalanche of antisemitic discourse in the social media $^{7}$ and mass manifestations, such as the November 11 marches (Poland's day of independence), rife with antisemitic displays, create a confusing picture. Recent data from the local Jewish population suggests a sharp increase in antisemitism over the past six years. ${ }^{8}$ This mixed picture may be indicative of the current situation in Poland whereby politics of the past have become entangled with politics of the present ${ }^{9}$ in what Snyder calls the "eternity" orientation: past and present are enmeshed into a continuous present. ${ }^{10}$ The inclination in Poland toward a narrow and negativistic nationalist public discourse has already been noted in a 2007 round table study ${ }^{11}$ with an emphasis on exposing the "enemies" of Poland and the Polish nation. In this context, Jewish negative stereotyping may act as a national identity building cement. ${ }^{12}$

3 D. Pinto, A New Jewish Identity for post-1989 Europe (London: Institute for Jewish Policy Research, 1996), 7.

4 Cf. R. E. Gruber, Virtually Jewish: Reinventing Jewish Culture in Europe (Berkeley: University of California Press, 2002); and M. Waligórska, "The Framing of the Jew: Paradigms of Incorporation and Difference in the Jewish Heritage Revival in Poland," in Framing Jewish Culture: Boundaries and Representations, ed. S. J. Bronner (Oxford: The Littman Library of Jewish Civilization, 2014), $313-34$.

5 Cf. Sułek, "Ordinary Poles."

6 Cf. B. Cohen, “The Dark Return of Polish Anti-Semitism,” Commentary 145, no. 3 (2018): 17-20, https://www.commentarymagazine.com/articles/ben-cohen/dark-return-polish-anti-semitism/.

7 Cf. R. Pankowski, “The Resurgence of Antisemitic Discourse in Poland," Israel Journal of Foreign Affairs (2018): 21-37.

8 Cf. European Union Agency for Fundamental Rights (FRA), Experiences and Perceptions of Anti-Semitism: Second Survey on Discrimination and Hate Crime against Jews in the EU (Luxembourg: European Union Agency for Fundamental Rights, 2018), https://fra.europa.eu/sites/de fault/files/fra_uploads/fra-2018-experiences-and-perceptions-of-antisemitism-survey_en.pdf.

9 Cf. K. Williams et al., "Explaining Lustration in Central Europe: A 'Post-Communist Politics' Approach,” Democratization 12, no. 1 (2005): 22- 43.

10 Cf. T. D. Snyder, The Road to Unfreedom: Russia, Europe, America (London: Harper, 2018).

11 Cf. D. Pinto, Voices for the Res Publica: The Common Good in Europe-Round Table Reports (London: Institute for Jewish Policy Research, 2009).

12 Cf. Waligórska, "The Framing of the Jew." 


\section{The Research Context}

The first documented mention of trade in Jewish figurines in Poland was traced to Krakow's Emmaus market of 1874 (an annual fair that continues to this day) when Mikołaj Wilczyński, a young bricklayer, sold three kopa (kopa = sixty items) of handmade Jewish figurines. ${ }^{13}$ Olga Goldberg-Mulkiewicz situates the carving of Jewish figurines in the eighteenth-century folk tradition of wood sculpturing, among which a Jewish figure in the shape of a beehive was not uncommon (placed in apiaries to garner a good yield). ${ }^{14}$ By the late nineteenth century, demand had driven the manufacture of a variety of costumed Jewish figurines-praying and studying, donning musical instruments but also featured as the devil. In the aftermath of World War II, Jewish figurines were no longer made, sold, or displayed. But a 1977 Emmaus market competition organised by the Krakow History Museum jointly with the Millennium Association of Folk and Artistic Handicrafts Producers, featured at least one producer, a certain Zdzisław Dudzik, who offered Jewish figurines. ${ }^{15}$

The fall of communism brought with it a decisive material change to the motif of the Jewish figurine, ${ }^{16}$ their most prominent attribute being a shiny one grosz coin-normally oversized compared to the size of the figurine, which is held by the figurine or is embedded in it. There are also pictures displaying a Jewish person seated behind a desk with a heap of gold coins, or absorbed in a book, carefully studying it. The figurine and the picture are believed to usher in "good luck," money more specifically, to its keeper. The purchaser of these artefacts takes them home (unless, which is also customary, they are offered as gifts) to display, sometimes as part of a collection, serving as talisman, protector of the premises and its inhabitants, and bearer of good luck and ma-

13 Cf. B. Pilichowska, “Krakowskie zabawki odpustowe przedstawiajace Żydów,” [“Krakow’s Church Fair Toys Depicting Jews,”] Polska Sztuka Ludowa 43, nos. 1-2 (1989): 129-33.

14 Cf. O. Goldberg-Mulkiewicz, "Postać Żyda w polskiej rzeźbie ludowej," [“The Figure of the Jew in Polish Sculpting,”] Polska Sztuka Ludowa-Konteksty 34, nos. 3-4 (1980): 219-26.

15 Cf. E. Duda, "Krakowskie odpusty Wielkanocne Krzysztofory,” [“Krakow’s St. Christopher's Easter Church Fairs,”] Krakow 6 (1979): 88-95.

16 Cf. R. E. Gruber, "Beyond Virtually Jewish: Monuments to Jewish Experience in Eastern Europe." in Framing Jewish Culture: Boundaries and Representations, ed. S. J. Bronner (Oxford: The Littman Library of Jewish Civilization, 2014), 335-56; and E. T. Lehrer, "Niepokojące pamiątki: kurator i muzeum w strefie konfliktów kulturowych (tłum. E. Klekot)” [“Disturbing Souvenirs: Curator and Museum in the Cultural Conflict Zone, trans. E. Klekot"] ZWAM: Zbiór Wiadomości Antropologii Muzealnej 2 (2015): 175-200, http://zwam.ptl.info.pl/wp-content/uploads/2015/03/ 21-Lehrer-2.pdf. 
terial wealth. Increasingly one finds these figurines displayed at work places, offices, and in shops too. ${ }^{17}$ In Krakow, in addition to the Emmaus market held annually on the second day of Easter, featuring stalls specialising in Jewish figurines, one finds them in practically all the souvenir shops in town, as indeed elsewhere throughout Poland.

Recent years have evidenced a growing mass media interest in the wealthgenerating Jewish figurine in Poland and abroad. However, it attracted less attention in academe. ${ }^{18}$ Scholars' common depiction of these figurines is as a symbol of deeply nostalgic memorabilia, with the specter of past Jewish Poland and the Holocaust never far away. ${ }^{19}$ Among scholarly accounts, Erica Lehrer's stands out. ${ }^{20}$ Lehrer views the Jewish figurines sold in Kazimierz (Krakow's historical Jewish neighborhood) and throughout Poland as objects of post-Jewish culture production, to include post-Holocaust tourism, contemporary Jewish cultural festivals (notably in Krakow), and the general interest in the Jewish-Polish past (and present) pervading Polish intellectual and popular culture. While Ruth Ellen Gruber highlights the oft-grotesque depiction of Jewish materiality in comparison to the actual reality and the past, ${ }^{21}$ for Lehrer this poses an opportunity to ask questions about identity, memory, and possible reconciliation. Jewish figurines, as well as other traces of Jewish culture production in contemporary Poland in Lehrer's view, are "everyday works of tolerance."22 They transform nar-

17 Cf. J. Tokarska-Bakir, "The Jew with the Coin: An Analysis of a Contemporary Folkloric Emblem," unpublished paper, accessed May 26, 2020, https://www.academia.edu/8995968/The Jew_with_a_Coin_Analysis_of_a_contemporary_folkloric_emblem.

18 Cf. S. Epstein, "Imaging Hasidim in Wood and PVC: Hasidic Figurines Made Today in Poland, Ukraine and Israel,” Zutot 6, no. 1 (2009): 131-40.

19 Cf. J. Marlow, review of Jewish Poland Revisited: Heritage Tourism in Unquiet Places, by Erica T. Lehrer, Holocaust and Genocide Studies 29, no. 2 (2015): 298-301; and J. D. Zimmerman, ed., Contested Memories: Poles and Jews During the Holocaust and its Aftermath (New Brunswick: Rutgers University Press, 2003).

20 Cf. E. T. Lehrer, “Can there Be a Conciliatory Heritage?” International Journal of Heritage Studies 16, nos. 4-5 (2010): 269-88; Lehrer, Jewish Poland Revisited: Heritage Tourism in Unquiet Places (Bloomington: Indiana University Press, 2013); Lehrer, "Repopulating Jewish Poland-in Wood,” Polin 16 (2003): 335-56; Lehrer, Na szczęście to Żyd: Polskie figurki Żydów [Lucky Jews: Poland's Jewish Figurines] (Kraków: Korporacja Haart, 2014); Lehrer, "Virtual, Virtuous, Vicarious, Vacuous? Towards a Vigilant Use of Labels," in Framing Jewish Culture: Boundaries and Representations, ed. S. J. Bronner (Oxford: The Littman Library of Jewish Civilization, 2014), 383-96; Lehrer, "Niepokojące pamiątki."

21 Cf. Gruber, "Beyond Virtually Jewish"; Gruber, "The Last Word," in Framing Jewish Culture: Boundaries and Representations, ed. S. J. Bronner (Oxford: The Littman Library of Jewish Civilization, 2014); 397-402; Gruber Virtually Jewish.

22 Lehrer, Jewish Poland Revisited, 17-18. 
row interpretations of the complex Polish-Jewish relationship by showing "how historical wounds can be both perpetuated and transcended, how new bridges can be built over old fissures, and the unanticipated companionship sometimes involved in managing the past."23 Lehrer was also the curator of an exhibition that took the format of a public dialogue, named "Souvenir, Talisman, Toy" in Krakow in Summer 2013 and which triggered debate in the media. Other scholars contextualized the Jewish figurine phenomenon as fitting into a Slavic tradition whereby peace to the household and good fortune required interaction with domestic demons. ${ }^{24}$ Hence the material object of the figurine embodies a magical demonic force that demands special ritualized treatments. ${ }^{25}$

Recent years have seen a drastic expansion of trade in business-to-consumer and consumer-to-consumer online. It was estimated, based on a world-wide survey, that at least seventy percent of survey respondents were undertaking some form of online consumer goods shopping activity, ${ }^{26}$ and user penetration in Poland is estimated to encompass two thirds of the population. ${ }^{27}$ The internet has also emerged as a major opinion exchange and opinion-making forum, whether through generic platforms such as Facebook or Twitter or in dedicated platforms, with the number of postings counting in the hundreds of millions. And there is a dark side too, notably when it comes to Jewish matters. In a comprehensive study of antisemitic discourse on German online sites, Monika Schwarz-Friesel found a three-fold increase in anti-Jewish content in internet "traffic" over a ten-year period. She concludes, "Internet communication thus accelerates both the transmission as well as the acceptance and normalization of anti-Jewish content." ${ }^{28}$ In post-communist Poland, a heightened sensitivity around censorship and freedom of speech may have accelerated antisemitic online discourse due

23 Ibid., 17.

24 Cf. J. Tokarska-Bakir, “Żyd z pieniążkiem podbija Polskę,” [“A Jew with a Coin Conquers Poland,”] Gazeta Wyborcza, February 18, 2012, https://wyborcza.pl/1,75410,11172689,Zyd_z_pie niazkiem_podbija_Polske.html?disableRedirects=true.

25 Cf. J. Tokarska-Bakir, Legendy o krwi: Antropologia przesądu [Blood Legends: An Anthropology of Exaggeration] (Warsaw: W.A.B., 2008).

26 Cf. P. Roesler, "New Research Reveals More Consumers Are Shopping Online for Everyday Items,” Inc., April 16, 2018, https://www.inc.com/peter-roesler/new-research-reveals-more-con sumers-are-shopping-online-for-everyday-items.html.

27 Cf. “eCommerce,” Statista, issued 2019, accessed May 26, 2020. https://www.statista.com/ outlook/243/146/ecommerce/poland.

28 M. Schwarz-Friesel, Antisemitism 2.0 and the Cyberculture of Hate: Hostility towards Jews as a Cultural Constant and Collective Emotional Value in the Digital Age (Short Version) (Berlin: Technical University of Berlin, 2018), https://www.linguistik.tu-berlin.de/fileadmin/fg72/Anti semitism_2.0_short_version_final2.pdf, 11. 
to the authorities' reluctance to mount a legal challenge against such expressions. $^{29}$

While the extant literature describes and debates the meaning of the phenomenon of Jewish figurines, to date we have only anecdotal evidence from the protagonists themselves-those most intimately engaged with the subject: producers, sellers, buyers-as to their reasons for this engagement and the meanings they attach to its practice. With the exception of one study, ${ }^{30}$ no other documented research comments on the online "presence" of the fortune-bearing figurine phenomenon, whether as a traded commodity or as a subject of public debate. We wish to rectify that in this paper and pose the following research questions:

- What aspects of wealth creation is the figurine endowed with?

- Why does the figurine hold these powers?

- How is the figurine activated (its modus operandi)?

- What are the artifacts' details, such as materials, size, and cost?

\section{Methods}

We conducted two studies over an eighteen-month period, searching the internet for information about Jewish figurines. In each study there were two periods of data collection. The first period of data collection was conducted August-September 2017 with a follow up in February-April 2019.

The approach we took was of an inductive qualitative inquiry, ${ }^{31}$ appropriate to an under-researched topic, anchored in an interpretative paradigm. We asked basic "what," "how" and "why" questions, namely: what does the online statement say, and what is the logic for saying so (where such an inference could safely be made from the text), aiming to generate reflexivity. ${ }^{32}$ In each website we examined all the relevant cases that came up in our search according to the key words employed (see below). We did not opt for pre-set categories so as to avoid bias and allow the phenomenon to reveal itself.

29 Cf. K. Gebert, "Poland and the New Anti-semitism," Index on Censorship 43, no. 1 (2014): $96-99$.

30 Cf. Tokarska-Bakir, "The Jew with the Coin."

31 Cf. M. Saunders et al., Research Methods for Business Students (Harlow: Pearson, 2016).

32 Cf. D. Jemielniak and M. Ciesielska, "Qualitative Research in Organization Studies," in Qualitative Methods in Organization Studies (New York: Springer, 2018), 1-5. 
Each identified case was manually content-analyzed ${ }^{33}$ for the identification of themes and patterns in the data. ${ }^{34}$ Our analysis aimed to recognize patterns (what and how questions) and obtain explanations (why questions).

\section{Study 1: Figurine Trade on the Internet}

The initial data collection was conducted from August 29, 2017 to September 3, 2017, examining the most relevant popular Polish online sites ${ }^{35}$ offering figurines and paintings featuring Jews. These were: Allegro.pl, Olx.pl, Jubileo.pl, Caneo.pl, Pamiątki.pl, Doye!, Sprzedajemy.pl, rzezbazdrewna.republika.pl, dolinakultury.pl, and savaart.flog.pl. The aspects explored covered all products being offered on the website, their price, and advertising statements that appeared in the description of the items. Keywords searched: Żydek (Jew boy), Żyd (Jew), Żydki (Jews), Żyd figurka (Jewish figurine), Żyd obraz (Jew painting), Żyd i praca (Jew and work). The follow up data collection was carried out on three days between February 20, 2019 to April 10, 2019 applying the same key words to the same online sites. ${ }^{36}$

Allegro.pl is probably the most popular online marketplace. In the course of our investigation, we identified 35 paintings and 117 figurines. Prices varied widely from $2.99 \mathrm{zł}$ to $550.00 \mathrm{zł}$. Typical accompanying statements include this detailed one:

\footnotetext{
"Jew in the hall-money in the pocket!" success. They are meant to bring happiness. In many forums and discussions, people who bought the picture confirm that after buying a picture with the image of a Jew, their fate has changed, they finally smiled happily, they got rid of troubles, worries or sorrows. So do not wait! Buy a picture of a Jew so you also will be happy in your home.” The same advert offers an incentive to buyers in the form of free adds-on:

"For all who buy the picture we have super gifts:

1) one NAIL IN GOLD COLOR-symbolizes the end of your problems ${ }^{37}$;

2) one GROSIK-the symbol of happiness;
}

"The picture with the image of a Jew is considered a symbol of fortune, prosperity or

33 Cf. K. Krippendorff, Content Analysis: An Introduction to Its Methodology (Los Angeles: Sage, 2004).

34 Cf. K. Locke, Grounded Theory in Management Research (London: Sage, 2001).

35 As per https://www.similarweb.com/top-websites/poland/category/shopping, last updated April 1, 2020, accessed May 26, 2020.

36 All proceeding quotes were translated from Polish to English by the authors of this article. 37 In Polish- "gwóźdź do trumny"-"nail into the coffin" means doomed to failure. 
3) one EUROCENT-same such coin in the European edition.”

There are several versions of the pictures, with headings such as: "Jew's table," "Jew with a lemon," "Jew with a newspaper," "Jew with a flashlight," "Jew with a candle," "Jew with a glass of wine." These pictures are produced in wholesale quantities; their price is about $3 \mathrm{zl}$. Similar ads on Allegro.pl refer to the sale of figurines as "TALISMAN FOR WEALTH!!! Jew at home brings happiness and wealth.”

On Pamiątki.pl 24 items were examined (price range $6 \mathrm{zl}, 10 \mathrm{zł}, 17 \mathrm{zł}$ ), with an emphasis on gift giving, for example:

An excellent souvenir from Krakow in the form of a Jewish figurine with magnet; it can be put on the fridge door. The magnets are laser-cut in plywood which gives an impressive three-dimensional appearance of the model.

On Doye! 57 items were found. The manufacturers specialize in magnets or pendants of figurines holding a grosz (golden coin) or a musical instrument, with the slogans "For the money and all the good fortune," "for luck and success" (price range $12.50 \mathrm{zl}$, to $30.00 \mathrm{zl}$ ). In its offer the company also includes standing figurines at a price of $6 \mathrm{zl}$ to $125 \mathrm{zl}$.

Sprzedajemy.pl is the largest free classifieds site in Poland with a large section on handicrafts. On this selling platform, the search found a total of 53 listings in our first search in 2017 and 47 items 18 months later. About a third of these were secondhand items (mostly paintings), and the rest were new (a broad range of figurines and paintings). Jewish figurines were commonly made of wood, some of clay. A typical advert comprised information on the item's aesthetic value and technical details (e.g., type of wood and dimensions), explanation of what could be expected as result of purchasing the product is also emphasized, and some ads suggest the best occasion to buy the item and how to display it:

\footnotetext{
Figurine made of clay, painted by hand with attention to every detail. A very impressive interior decoration for home or office. Jews' wisdom (know-how) to get rich and be happy, is derived from the Torah. The Jew has always been a symbol of success in business and personal life. I recommend it as a perfect and original gift idea for a new home, for the opening of a new business or as a decoration for an office space.
}

The artisan-crafted Jewish figurines start at upwards of $90 \mathrm{zł}$. A typical advert runs: 
Today for sale I have figurines made of linden wood. The figures depict Jews with bags, crates and barrels of money that bring success in finance. Perfect for a unique gift.

At the craftsman's own website Firma Wood-World Michat Widziszewski one reads:

Jewish figurines made in lime tree, painted, stained and pasted. They present various figures such as accountants, bankers, musicians. Possibility to order any quantity. Perfect gift idea. Figures endowed with good luck. ${ }^{38}$

The paintings on sale usually depict a Jewish man in traditional or business attire, counting money. An advert for a picture titled "Jew with money" states:

According to many people it really works. Superstition is very popular among financiers, bankers, brokers-anywhere where money matters. A Jew who counts money has positive associations as a symbol of a great businessman who wisely invests and wisely saves money. Jews have always been and are a financial elite, have multi-generational traditions of activity in the financial markets, associated with wise and cautious investment. A Jew whose money has only positive associations is a good superstition about a successful man who is specialized in trading and knows how to make money. This is a good example for us and a source of benefits. The figurine should be placed near the entrance door to the house; and in a business, located at the entrance.

This is the longest statement found online for selling a painting, echoing common arguments many other sellers use. It captures the tone and sentiment of the typical advertisement, aiming to capitalize on ingrained folkloric beliefs.

Olx.pl is a nationwide service for advertisements, where figurines and pictures of Jews for sale are placed in the category of "interior decorations" as well as under "hobbies/collections." We found 35 items, mostly paintings, with a wide price range $5 \mathrm{zt}$ to $900 \mathrm{zt}$. The Jubileo.pl website, which sells women's and men's jewelry, also features figurines. An example of an item for sale (the accompanying explanation is the opening paragraph of this article) is titled: "Figurine of Jew with Seal Symbol of Fortune." The subtitle reads: "Standing Jewish figurine with pouch, made of base metal in the color of old gold" (see image 1.) Dolina Kultury is an online shop selling artistic handicrafts that also offers wooden figurines. The content of one of the ads reads:

Figurine of a Jew holding a violin carved from linden wood and waxed. It is said to bring fortune-as the old folk proverb says, "Who hasn't got a Jew at home-that person is awaiting poverty."

38 http://rzezbazdrewna.republika.pl/ [no longer accessible]. 
The advertised figure sells for $350 \mathrm{zt}$.

Ceneo.pl is an online price comparison site where one can find shops offering, among other gadgets, Jewish figurines. For example, a figurine alongside a wooden box on the shop page "Stylish Souvenirs" 39 or on the website sklepzupominkami.com.pl: "Jewish figurine. Jew with grosz. For (gaining) a lot of money." 40 On Saavart.flog.pl, ads can be found of figurines such as those sold at the time of Emmaus in Krakow:

Figurines of Jews (tradition of the Emmaus of Krakow). Figures about $25-35 \mathrm{~cm}$. high. Moving on mysterious springs ;-) the effect of our work. Collector's Edition. ${ }^{41}$

\section{In Summary}

Figurines and related objects (pictures) are abundant in online Polish consumer sites. They are advertised primarily as objects that are to bring financial success and prevent financial failure or protect against unnecessary expenses. The figurines or pictures most commonly depict a Jewish man with a coin or another monetary/financial instrument (pouch, portfolio, accounting book). Aimed for indoor decoration or as a gift, also as a souvenir, with a wide price range reflecting the quality of the product and whether it is handmade or mass produced. Among the cheapest are magnet figurines costing a few zlotys; the most expensive are artistic handicrafts (several dozen to several hundred zlotys). The ads often advise on how and where to display the image and sometimes provide elaborate handling instructions.

\section{Study 2: Online Forums}

The first phase of data collection was conducted over two weeks in September 2017. Overall 57 comments were counted that relate directly to the trade and collection of Jewish figurines and pictures. In early March 2019, these forums were revisited and the lack of new comments was apparent.

39 https://www.stylowe-upominki.pl/en/p/SKRZYNKA-NA-KEYS-WOODEN-ZYD-NA-luck/2148 [no longer accessible].

40 http://sklepzupominkami.com.pl/na-szczescie/2749-figurka-zyda-zydek-naszczescie.html [no longer accessible].

$41 \mathrm{http}: / /$ savaart.flog.pl/wpis/4573697/zydki-emausowe-figurki-o-wysokosci-okolo-2535-cm-por uszajace-sie-na-tajemniczych-sprezynach, issued April 1, 2012, accessed May 26, 2020. 


\section{Szafal (szafal.pl) $)^{42}$}

Under the heading "for luck," the question this forum debates is how to hang a picture depicting a Jew in order "to make it happy" (note that the artifact is imbued with life-like qualities, such as the ability to be made "happy"). An exchange took place between 2009 and 2013. Here are some comments:

I have heard that a Jewish picture hung in the house (usually near the entrance door) guarantees money at home. Some people believe that the general possession of any Jewish figurine makes our money "held"... but is it right to believe so? In my opinion this is just superstition, although I don't mind .... faith works wonders [asiunia2706, October 21, 2011.]

My mom has a figurine, she has to put it upside down on Friday and turn it back upright on Sunday, I guess. But my mother is not a good example of the miraculous power of the Jew... [Ilmina, Ocotber 21, 2011.]

... I have not heard of the advantages of a Jew, but if a Jew is successful, I will gladly invite him to my home. [Yrsa, February 20, 2009]

(...) I don't believe it, but on the other hand ... Don't mind it to hang for me ... or maybe just happily to smile to me ... :)))) [aagaa, February 21, 2009]

(...) I have had 3 Jewish figurines in my house for a few years now and I find that there is something in it. I will not write here that I made a fortune and I have villas with a swimming pool and 3 cars; no :) but I don't complain and somehow am successful with everything. Maybe that's the case and maybe it just affects positive thinking ... I don't know, I believe in it and I will not give them to anyone. It is said that to bring on this wealth you have to get it (the figurine) from someone and not buy it yourself :) [Anonymous, June 20, 2010]

\section{Sklep z Upominkami (sklepzupominkami.com.pl..43 and Srebrana Agrafka (http://www.srebrnaagrafka.pl) ${ }^{44}$}

These websites provide explanations about the importance of Jewish images and figurines as well as tips on how to engage with them so as to make one successful:

The Jews have always symbolized great businessmen, wise and scrupulous people. That's why the figurine has two things: it attracts money and protects you from unnecessary expenses.

There are, however, several rules for the Jew to make financial success:

42 http://forum.szafa.pl/84/4746068/zydek-na-szczescie.html, accessed May 26, 2020.

43 http://sklepzupominkami.com.pl/na-szczescie/2259-figurka-zydek-na-szczescie-prezent.html [no longer accessible].

44 http://srebrnaagrafka.pl/sklep/anielskiewariacje/produkt/zydek-na-szczescie-i-pieniadze [no longer accessible]. 
1) Jew should be middle-aged with beard and gray-which symbolizes his maturity, knowledge and experience.

2) Should hold (count) money

2) Hang the figurine in the corridor above the entrance door or the left side of the door, which symbolizes successful business, and always look at him before leaving the house.

3) At the end of the year and on Saturday (Sabbath day), turn the figurine upside down and shake it, so the accumulated money will return to the house where it belongs to.

4) At the workplace the figurine should be in the boss's office to make the business profitable.

\section{Bobe Majse (bobemajse.blogspot.com) $)^{45}$}

\section{This exchange took place in September 2011. Here are some excerpts:}

(...) as the old folk wisdom says, when one can't change something, one must love one another. Fight the superstition of grabbing the button and counting up to ten at the chimney sweep, or the temptation to touch the humpbacked "for luck"? It's more or less the same category as a Jew with mammon. [ Anonymous, September 11, 2009]

Such images have long been disgusting me, there are plenty of them (you did not notice?), Because there is a superstition that such a picture or figure bring happiness in business. It's a curiosity even in my local pizzeria:) And in many homes. It is depressing, but it testifies to some pre-war associations. Such a grim calling. [Sara, June 5, 2011]

In many homes of friends of my mother's age-hanging on the walls, among the images of angels, hangs a portrait of a Jew counting money. I once asked my mother why a Jewish man with money is hanging there (I didn't know anything about the meaning of that portrait) and I received the explanation that such a portrait brings financial HAPPINESS. Just as the angels take care of the peace and health of the household members, the portrait of the Jew is to bring about a lack of hunger, financial liquidity, a sense of (financial) security (...) [Green Canoe, June 14, 2011]

\section{Forum Rzeźbiarzy (forum.rzezbiarz.idl.pl) ${ }^{46}$}

Commentaries refer to the fact that the main purpose of owning and collecting figurines is financial gain and happiness:

45 http://bobemajse.blogspot.com/2011/09/bez-komentarza.html, issued September 10, 2011, accessed May 26, 2020.

$46 \mathrm{http}: / /$ www.forum.rzezbiarz.idl.pl/viewtopic.php/t=1322\&start=60\&sid= b56f9b2ebfd012932354fba035b8d53f [no longer accessible]. 
Hello, Mirek, thanks for visiting, I will tell you honestly that the Jew fad is not bad. (...) [koand, April 28, 2011]

The Jews are fairy-tale without proportion, it is a symbol to bring happiness [wacek 721, May 5 , 2011]

\section{Summary of the Discourse}

With various extrapolations (on superstitious beliefs, Jews and Poles in general) the discourse focuses on providing or refuting evidence about the efficacy of the figurines (pictures) to usher in wealth and good fortune to their owners. The attitude toward these objects is functional and confined to their "utility." Few comment on relevant aesthetic (decorative, ornamental) aspects.

\section{Discussion}

The Jewish figurine as an aide-mémoire of Jews in Polish history fluctuates between personal and collective memory of the past, ${ }^{47}$ yet principally evoked here and now is its utility in the service of an individual's finances in the context of the new, post-Communist Polish market economy. Thus the phenomenon of trading figurines of Jews on the internet is truly contemporary, capturing the transformative journey of Poland from a socialist command economy to private facing capitalist enterprise, along with current tastes, purchasing trends, and new methods of marketing.

The essentialization of the figurine as a magic-demonic device for enrichment and avoidance of financial mishap also serves to emphasize the differences between "us" (Poles) and "them" (Jews). This mindset is prone to stereotyping, which in Polish history of the past century has been overwhelmingly negative. ${ }^{48}$ The discourse around these artefacts is mostly concerned with procedures to enact them; an exchange between experienced "figurine handlers" and the novices who look out for guidance from those well versed in the incantation procedure.

47 Cf. J. Nowak, “Żydowscy sąsiedzi: o więziach społecznych w pamięci mieszkańców południowej Polski," ["Jewish Neighbors: On Social Bonds in the Memory of the Inhabitants of Southern Poland,”] Lud 100 (2016): 209-32, https://apcz.umk.pl/czasopisma/index.php/LUD/article/ view/lud100.2016.00/14543.

48 Cf. Tokarska-Bakir, Legendy o krwi. 
It is difficult to reconcile our data with Polish benevolent, conciliatory, bridge-building well-meanings, such that Lehrer finds. ${ }^{49}$ That is so whether we consider the grotesque deed itself, ${ }^{50}$ whereby symbolic violence is mitigated against a figure of an old man (hanging it upside down), imbuing it with magic powers to enrich or ruin-unsurprisingly, in the latter case, the figure may end going up in smoke (literally, with unavoidable shocking Shoah connotations) as Tokarska-Basir reports the following exchange on the internet:

Dear friends! I must warn you! Recently, I have tried out the Jew myself, and I still can't get over it! After a few months of hanging in the entrance hall, he just let us go bankrupt. My husband threw him in the fire, and he didn't even allow me to keep the frame. ${ }^{51}$

Neither does the overall cultural/linguistic context facilitate a neutral (let alone positive) interpretation. ${ }^{52}$ The standard reference words $\dot{Z} y d, \dot{Z} y d z i, \dot{Z} y d y, \dot{Z} y d k i$ are well ingrained in the Polish language and culture with a clear pejorative bias. ${ }^{53}$ Incantation references dominate the trading discourse on the internet, and they are sufficiently robust to sideline reflection and critical thinking about the consequences of reification. Those voices that try to expose the negative connotations are the exception in this discourse.

The analytical interpretation we have undertaken deals with the visible content of the discourse, often underlined with arguments that justify conduct by offering logical explanations and "factual" evidence. However, there is also an invisible, implicit layer to the discourse, which resonates with a subconscious cultural stand. It is difficult to discern that from the narratives at out disposal, since they tend to be short and, as we do not have recourse to the protagonists generating them for further clarifications. Nevertheless, a few exchanges on the internet amount to more than a terse paragraph that may lend itself to such analysis. Thus the following vignette stands out among our examples as a complete story.

49 Cf. Lehrer, “Can there Be a Conciliatory Heritage?”; Lehrer, Jewish Poland Revisited; Lehrer, "Niepokojące pamiątki."

50 Cf. Tokarska-Bakir, "The Jew with the Coin."

51 Ibid., 9.

52 Cf. A. Cała, Wizerunek Żyda w polskiej kulturze ludowej [The Image of the Jew in Polish Folk Culture] (Warsaw: Wydawnictwo Uniwersytetu Warszawskiego, 1992); and A. Wierzbicka, "Żyd, Żydzi, Żydy, Żydki: Stereotypes and Judgments Ingrained in the Polish Language,” Acta Universitatis Lodziensis: Folia Linguistica 49 (2015): 57-67.

53 Cf. Wierzbicka, “Żyd, Żydzi, Żydy, Żydki.” 
Hello. I wanted to write something about this image. I am a businessman and I have often seen such paintings in law offices, consultancy offices, real estate brokers and I will tell you. The first time I saw this picture I didn't dare ask anyone why this picture hangs. You know why? Because I was scared to offend someone, in case it was a relative, and also because asking someone such a question might put me in an embarrassing light. After a while, and I came across this picture again, and it did not give me peace. I had such a strange feeling that finally I also hung such a picture at home. How did my business do? Before then I have been working hard but others would benefit from my work. After I hung up this image, strange things started to happen. The people I used to do business with suddenly started calling me, meeting me, and above all, playing honestly with me. So you have the answer if it really works. My hunch and lesson from life is that hard work led me to this picture-I wish not so late! ${ }^{54}$

The context here is business and enterprise. The narrator first noticed the picture of a Jew with money hanging in an office. The protagonist did not wish to enquire about it since he thought it might not be polite to do so and possibly insinuate that the owner has Jewish relatives, which may be embarrassing. Then he (let's assume it is a he) saw the picture in other similar establishments and finally acquired one. Since then his business situation changed for the better. Whereas before he may have had to chase opportunities and may have been taken advantage of, after hanging the picture, clients started to pursue him and deal with him honestly. Hence the picture acts in a dual capacity: as a good luck device it generates customers and as a shield against harm, it counteracts dishonesty.

The tone of the narrative is neutral. There are no judgmental statements except making the point that the narrator deserves the fruits of his hard work (i.e., he earned the right to find out a "trick" others benefited from), though he is somewhat unlucky not having come across it sooner. The undertone reveals the following: having a Jew as relative is embarrassing; an image of a Jew works wonders, demonstrating omnipotence, thereby attributing Jews the might to provide and to ruin. That is necessary because the world is a difficult and deceitful place. Decent folks can't succeed just by hard honest work. One needs magical (demonic?) assistance. Jews, through their image representation, can supply that. People know about this "trick," but they may not share that knowledge willingly.

54 http://bobemajse.blogspot.com/2011/06/obraza.html, issued June 5, 2011, accessed May 26, 2020. 
Shulamit Volkov's well-known thesis about antisemitism as a socio-cultural code resonates here. ${ }^{55}$ Volkov considers a socio-cultural code a position on a given issue that whilst playing a marginal role in the worldview of protagonists, nevertheless holds wide-ranging ramifications. The vast majority of Poles know next to nothing about contemporary Jews. Jews do not constitute a significant object in their everyday cognitions. The perception of and about Jews however does have a bearing on their (national) identity. Polish national identity as forged through history has been marked by a self-perception of Poland as the suffering nation: Poland "Christ among nations," "the martyr of Europe,"56 plagued with external as well as internal enemies, prime amongst the latter are the Jews. ${ }^{57}$ The post-Communist revival of interest in Poland's Jewish past and the revelations (such as by historian Jan Tomasz Gross) about Polish complicity with Nazi atrocities, as well as post-World War II pogroms, challenges this image of Poland and Poles as victims. Jews once again, are on the Polish public agenda.

What we seem to get from this narrative is a reversed identification (transference) with the aggressor, similar to what one witnesses on the football pitches in present-day Poland, ${ }^{58}$ whereby football club fans' verbal exchanges are infused with insults and derogatory remarks about Jews. In these remarks, dominated by re-imagining Poland under Nazi occupation, the "attacking" fans assume the role of the Nazi persecutor, while their rivals are the suffering Jews. In our case here the image of the omnipotent Jew, represented in the shape of a wooden (clay, plastic) figurine, is incorporated into the psychic space of the protagonist, in what William James called "the will to believe that things tell a story." 59

55 Cf. S. Volkov, "Anti-Semitism as a Cultural Code: Reflections on the History and Historiography of Anti-Semitism in Imperial Germany," Yearbook of the Leo Baeck Institute 23 (1978): 25-46; and Volkov, "Readjusting Cultural Codes: Reflections on Anti-Semitism and Anti-Zionism," Journal of Israeli History 25, no. 1 (2006): 51-62.

56 Cf. A. Zybała, Polski umyst na rozdrożu: wokót kultury umysłowej w Polsce [The Polish Mind at a Crossroad: About Intellectual Culture in Poland] (Warsaw: Oficyna Wydawnicza SGH, 2016). 57 Cf. J. B. Michlic, Poland's Threatening Other: The Image of the Jew from 1880 to the Present (Lincoln: University of Nebraska Press, 2006); and A. Cała, Żyd-wróg odwieczny? Antysemityzm w Polsce i jego źródta [The Jew-the Eternal Enemy? Antisemitism in Poland and its Origins] (Warsaw: Wydawnictwo Nisza, 2012).

58 Cf. J. Tokarska-Bakir, "The Open Secret: Victims, Perpetrators, Witnesses and Bystanders in Polish Public Discourse at the Beginning of the 21st Century," in Intellectual Anti-Semitism: Comparative Studies from a Global Perspective, ed. S. K. Danielsson and F. Jacob (Würzburg: Königshausen \& Neumann GmbH, 2018), 223-58.

59 Quoted in D. M. Boje, Storytelling Organizational Practices: Managing in the Quantum Age (London: Routledge, 2014), 187. 
Socio-cultural codes according to Volkov signify larger important life positions, which stand out in particular at times of crisis and polarity, as was the case, for example, during the Dreyfus affair in France. Dreyfusians and antiDreyfusians employed antisemitism as a marker on bigger issues such as Republicanism, the juridical system, and the role of the army in society. In our narrative the Jewish figurine plays a role in new, post-Communist Poland, with its drive for economic expansion and personal financial success. The protagonist's position is ambivalent. He wishes to join those financial success stories but that may not be achievable by one's efforts alone. The skills and competence required in the new Poland are beyond the modest honest workman; they call for magical-demonic support; and in Polish national-traditional cognition no one would do better than "The Jew." Upholding or opposing such beliefs about Jews are a marker to other key positions. According to the latest data, ${ }^{60}$ present-day antisemites (who hold Jews responsible for world economic upheaval ${ }^{61}$ ) as against the modern "anti-antisemites" ${ }^{62}$ split on a host of cardinal issues on the Polish national agenda such as the economy, religion, and political affiliation. Thus antisemitism in contemporary Poland acts as a marker, a socio-cultural code. The humble figurine of the Jew with a coin plays a key role in Polish affairs: History's vengeance?

Professor Yochanan Altman's interest in antisemitism is recent. As Gastprofessor with the WU Vienna, he is developing work on antisemitism in the workplace. Educated in business psychology and organizational anthropology, Yochanan is Editorin-Chief of European Management Review and Founding Editor of the Journal of Management, Spirituality \& Religion. He also launched the book series on Management, Spirituality \& Religion to be published by De Gruyter.

Roman Batko is Professor in Management Science at the Jagiellonian University and member of the Culture and Media Management Committee of the Polish Academy of Arts and Sciences. He specializes in humanistic management, process management, audits and evaluation systems, innovation management, digital strategies, and automation. His research focuses on issues related to the so-called organizations of the future: robotization, cyborgization, new forms of communica-

60 The data referenced here are extensive surveys conducted in 2011 and 2012 respectively. Hence they predate the rise to power of the nationalist PiS government in 2015. Cf. Sułek, "Ordinary Poles"; and I. Krzemiński, "Polish National Antisemitism," Polin 31 (2019): 515-42.

61 Cf. H. Arendt, The Origins of Totalitarianism (Part 1: Antisemitism) (San Diego: Harcourt Brace, 1951); and Volkov, "Readjusting Cultural Codes."

62 Cf. Volkov, "Readjusting Cultural Codes"; and Krzemiński, "Polish National Antisemitism." 
tion, issues related to changes in the labor market, as well as the creation of technological networks in which the position of a human changes radically.

Professor Mark Davies has published widely in marketing strategy and is currently Editor-in-Chief of the Journal of Brand Management and an Associate Editor of European Management Review. Relevant to this study of Jewish figurines, he has interests in collectibles in the creative industries and how religious norms and folklore influence online marketing strategies.

Katarzyna Baliga-Nicholson holds a master's degree in management from the Jagiellonian University. She conducts research on organizational consequences of developing artificial intelligence, specifically in the area of voice technologies, the interaction of people and bots, and relationships between technology and art. She is currently a doctoral candidate at the Jagiellonian University.

\section{References}

Arendt, Hannah. The Origins of Totalitarianism (Part 1: Antisemitism). San Diego: Harcourt Brace, 1951.

Batko, Roman. “Identity of Place - Revitalization of Memory. Home, Sanctuary, Cemetery.” In Contemporary Understanding of Revitalization in Poland, edited by Aleksander Noworól and Krzysztof Skalski, 97-117. Kraków: Monographs and Studies of Jagiellonian University Institute of Public Affairs, 2010.

Batko, Roman. "The Vacuum and the Imagination of Space: The Cultural Role of Żyznowski Publishing House." In Faces of Identity and Memory: The Cultural Heritage of Central and Eastern Europe (Managing and Case Studies), Ewa Kocój and Lukasz Gawet, 89-111. Kraków: Jagiellonian University Press, 2015.

Boje, David M. Storytelling Organizational Practices: Managing in the Quantum Age. London: Routledge, 2014.

Cała, Alina. Wizerunek Żyda w polskiej kulturze ludowej. [The Image of the Jew in Polish Folk Culture.] Warsaw: Wydawnictwo Uniwersytetu Warszawskiego, 1992.

Cała, Alina. Żyd-wróg odwieczny? Antysemityzm w Polsce i jego źródta. [The Jew-the Eternal Enemy? Antisemitism in Poland and its Origins.] Warsaw: Wydawnictwo Nisza, 2012.

Cohen, Ben. "The Dark Return of Polish Anti-Semitism." Commentary 145, no. 3 (2018): 17-20. https://www.commentarymagazine.com/articles/ben-cohen/dark-return-polishanti-semitism/.

Duda, Eugeniusz. "Krakowskie odpusty Wielkanocne Krzysztofory.” [“Krakow’s St. Christopher's Easter Church Fairs.”] Krakow 6 (1979): 88-95.

Epstein, Shifra. "Imaging Hasidim in Wood and PVC: Hasidic Figurines Made Today in Poland, Ukraine and Israel." Zutot 6, no. 1 (2009): 131-40.

European Union Agency for Fundamental Rights (FRA). Experiences and Perceptions of Anti-Semitism: Second Survey on Discrimination and Hate Crime against Jews in the EU. 
Luxembourg: European Union Agency for Fundamental Rights, 2018. https://fra.europa. eu/sites/default/files/fra_uploads/fra-2018-experiences-and-perceptions-of-antisemitismsurvey_en.pdf.

Gebert, Konstanty. "Poland and the New Anti-semitism." Index on Censorship 43, no. 1 (2014): 96-99.

Goldberg-Mulkiewicz, Olga. "Postać Żyda w polskiej rzeźbie ludowej.” [“The Figure of the Jew in Polish Sculpting.”] Polska Sztuka Ludowa-Konteksty 34, nos. 3-4 (1980): 219-26.

Gruber, Ruth Ellen. "Beyond Virtually Jewish: Monuments to Jewish Experience in Eastern Europe." In Framing Jewish Culture: Boundaries and Representations, edited by Simon J. Bronner, 335-56. Oxford: The Littman Library of Jewish Civilization, 2014.

Gruber, Ruth Ellen. "The Last Word." In Framing Jewish Culture: Boundaries and Representations, edited by Simon J. Bronner, 397-402. Oxford: The Littman Library of Jewish Civilization, 2014.

Gruber, Ruth Ellen. Virtually Jewish: Reinventing Jewish Culture in Europe. Berkeley: University of California Press, 2002.

Jemielniak, Dariusz, and Malgorzata Ciesielska. "Qualitative Research in Organization Studies." In Qualitative Methods in Organization Studies, 1-5. New York: Springer, 2018.

Krippendorff, Klaus. Content Analysis: An Introduction to Its Methodology. Los Angeles: Sage, 2004.

Krzemiński, Ireneusz. "Polish National Antisemitism.” Polin 31 (2019): 515-42.

Lehrer, Erica T. “Can there Be a Conciliatory Heritage?” International Journal of Heritage Studies 16, nos. 4-5 (2010): 269-88.

Lehrer, Erica T. Jewish Poland Revisited: Heritage Tourism in Unquiet Places. Bloomington: Indiana University Press, 2013.

Lehrer, Erica T. Na szczęście to Żyd: Polskie figurki Żydów [Lucky Jews: Poland’s Jewish Figurines]. Kraków: Korporacja Haart, 2014.

Lehrer, Erica T. "Niepokojące pamiątki: kurator i muzeum w strefie konfliktów kulturowych (ttum. E. Klekot)." [“Disturbing Souvenirs: Curator and Museum in the Cultural Conflict Zone, trans. E. Klekot.”] ZWAM: Zbiór Wiadomości Antropologii Muzealnej 2 (2015): 175-200. http://zwam.ptl.info.pl/wp-content/uploads/2015/03/21-Lehrer-2.pdf. Lehrer, Erica T. “Repopulating Jewish Poland-in Wood.” Polin 16 (2003): 335-56. Lehrer, Erica T. "Virtual, Virtuous, Vicarious, Vacuous? Towards a Vigilant Use of Labels." In Framing Jewish Culture: Boundaries and Representations, edited by Simon J. Bronner, 383-96. Oxford: The Littman Library of Jewish Civilization, 2014.

Locke, Karen. Grounded Theory in Management Research. London: Sage, 2001.

Marlow, Jennifer. Review of Jewish Poland Revisited: Heritage Tourism in Unquiet Places, by Erica T. Lehrer. Holocaust and Genocide Studies 29, no. 2 (2015): 298-301.

Michlic, Joanna Beata. Poland's Threatening Other: The Image of the Jew from 1880 to the Present. Lincoln: University of Nebraska Press, 2006.

N. N. "Jew Dolls \& Other Ethnic Toys." Shtetl Montreal, June 29, 2013. http://shtetlmontreal. com/2013/06/29/jew-dolls-other-ethnic-toys/.

Nowak, Jacek. "Żydowscy sąsiedzi: o więziach społecznych w pamięci mieszkańców południowej Polski." [“Jewish Neighbors: On Social Bonds in the Memory of the Inhabitants of Southern Poland."] Lud 100 (2016): 209-32. https://apcz.umk.pl/czaso pisma/index.php/LUD/article/view/lud100.2016.00/14543. 
Pankowski, Rafat. "The Resurgence of Antisemitic Discourse in Poland.” Israel Journal of Foreign Affairs (2018): 21-37.

Pilichowska, Bogdana. “Krakowskie zabawki odpustowe przedstawiajace Żydów.” [“Krakow’s Church Fair Toys Depicting Jews.”] Polska Sztuka Ludowa 43, nos. 1-2 (1989): 129-33.

Pinto, Diana. A New Jewish Identity for post-1989 Europe. London: Institute for Jewish Policy Research, 1996.

Pinto, Diana. Voices for the Res Publica: The Common Good in Europe-Round Table Reports. London: Institute for Jewish Policy Research, 2009.

Roesler, Peter. "New Research Reveals More Consumers Are Shopping Online for Everyday Items.” Inc., April 16, 2018. https://www.inc.com/peter-roesler/new-research-revealsmore-consumers-are-shopping-online-for-everyday-items.html.

Saunders, Mark, Philip Lewis, and Adrian Thornhill. Research Methods for Business Students. Harlow: Pearson, 2016.

Schwarz-Friesel, Monika. Antisemitism 2.0 and the Cyberculture of Hate: Hostility towards Jews as a Cultural Constant and Collective Emotional Value in the Digital Age (Short Version). Berlin: Technical University of Berlin, 2018. https://www.linguistik.tu-berlin.de/ fileadmin/fg72/Antisemitism_2.0_short_version_final2.pdf.

Sutek, Antoni. "Ordinary Poles Look at the Jews." East European Politics and Societies and Cultures 26, no. 2 (2012): 425-44.

Snyder, Timothy D. The Road to Unfreedom: Russia, Europe, America. London: Harper, 2018.

Statista. "eCommerce." Issued 2019. Accessed May 26, 2020. https://www.statista.com/out look/243/146/ecommerce/poland.

Tokarska-Bakir, Joanna. "The Jew with the Coin: An Analysis of a Contemporary Folkloric Emblem." Unpublished Paper. Accessed May 26, 2020. https://www.academia.edu/ 8995968/The_Jew_with_a_Coin_Analysis_of_a_contemporary_folkloric_emblem.

Tokarska-Bakir, Joanna. Legendy o krwi: Antropologia przesądu. [Blood Legends: An Anthropology of Exaggeration.] Warsaw: W.A.B., 2008.

Tokarska-Bakir, Joanna. "The Open Secret: Victims, Perpetrators, Witnesses and Bystanders in Polish Public Discourse at the Beginning of the 21st Century." In Intellectual Anti-Semitism: Comparative Studies from a Global Perspective, edited by Sarah K. Danielsson and Frank Jacob, 223-58. Würzburg: Königshausen \& Neumann GmbH, 2018.

Tokarska-Bakir, Joanna. "Żyd z pieniążkiem podbija Polskę.” [“A Jew with a Coin Conquers Poland.”] Gazeta Wyborcza, February 18, 2012. https://wyborcza.pl/ 1,75410,11172689,Zyd_z_pieniazkiem_podbija_Polske.html?disableRedirects=true.

Volkov, Shulamit. "Anti-Semitism as a Cultural Code: Reflections on the History and Historiography of Anti-Semitism in Imperial Germany." Yearbook of the Leo Baeck Institute 23 (1978): 25-46.

Volkov, Shulamit. "Readjusting Cultural Codes: Reflections on Anti-Semitism and Anti-Zionism." Journal of Israeli History 25, no. 1 (2006): 51-62.

Waligórska, Magdalena. "The Framing of the Jew: Paradigms of Incorporation and Difference in the Jewish Heritage Revival in Poland." In Framing Jewish Culture: Boundaries and Representations, edited by Simon J. Bronner, 313-34. Oxford: The Littman Library of Jewish Civilization, 2014.

Wierzbicka, Agnieszka. “Żyd, Żydzi, Żydy, Żydki: Stereotypes and Judgments Ingrained in the Polish Language.” Acta Universitatis Lodziensis: Folia Linguistica 49 (2015): 57-67. 
Williams, Kieran, Brigid Fowler, and Aleks Szczerbiak. "Explaining Lustration in Central Europe: A ‘Post-Communist Politics' Approach.” Democratization 12, no. 1 (2005): $22-43$.

Zimmerman, Joshua D., ed. Contested Memories: Poles and Jews During the Holocaust and its Aftermath. New Brunswick: Rutgers University Press, 2003.

Zybata, Andrzej. Polski umyst na rozdrożu: wokót kultury umystowej w Polsce. [The Polish Mind at a Crossroad: About Intellectual Culture in Poland.] Warsaw: Oficyna Wydawnicza SGH, 2016. 